\title{
The effect of hypertension on survival in patients undergoing radiotherapy for brain metastasis
}

\section{Beyin metastazı tanısı ille radyoterapi uygulanan hastalarda hipertansiyonun sağkalıma etkisi}

\author{
Eda Erdiş, Birsen Yücel
}

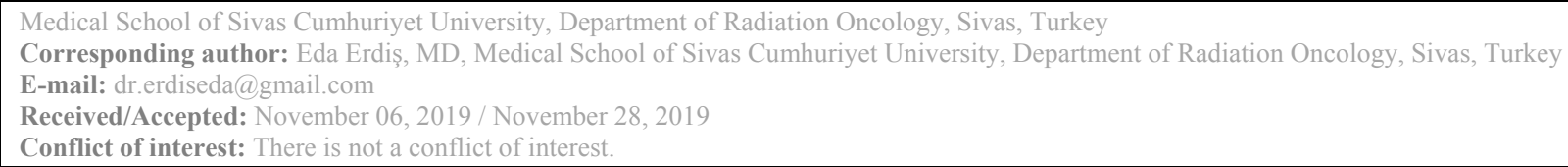

\section{SUMMARY}

Objective: The prognosis of brain metastasis is very poor and the survival period is very short if the patient is not treated. The determination of prognostic factors is important in order to avoid invasive treatment interventions or unnecessary treatment in the management of patients with brain metastases. In this study, prognostic factors and the effect of hypertension on survival in patients with brain metastasis were investigated.

Method: In this study, the data of 463 patients diagnosed with brain metastasis, who were admitted to Cumhuriyet University Radiation Oncology department between 2007 and 2018, were retrospectively analyzed.

Results: The median age was 59 (18-82) years. There were 170 (37\%) patients with comorbidity and $23 \%$ of these patients had hypertension in their medical history. With regard to primary cancer diagnoses, $271(58 \%)$ patients had lung cancer, 91 (20\%) breast, $31(6 \%)$ gastrointestinal, 21 (5\%) genitourinary, 13 (3\%) gynecological, $11(2 \%)$ unknown cancer and $25(5 \%)$ had other types of cancer. At the time of diagnosis, 217 patients $(47 \%)$ were in a metastatic stage. Median survival was 4 months $(0-130$ months); mean survival was $9.74+0.6$ months; 1 -year survival was $27 \%$ and 2 -year survival was $13 \%$. In univariate analysis, gender $(p=.001)$, age $(\mathrm{p}<.001)$, hypertension $(\mathrm{p}=.018)$, primary diagnosis $(\mathrm{p}<.001)$, RPA $(\mathrm{p}$ $<.001)$, number of lesions ( $\mathrm{p}<.001)$, SRS $(\mathrm{p}<.001)$, metastatectomy $(\mathrm{p}<$ $.001)$ and primary disease status $(\mathrm{p}=.002)$ were statistically significant. Multivariate analysis showed that hypertension (HR: 1.29, 95\%; CI: 1.02$1.71 ; \quad \mathrm{p}=.027$ ), age (HR: $1.39,95 \%$; CI: $1.08-1.77 ; \mathrm{p}=$ .008 ), primary diagnosis (HR: $1.63,95 \%$; CI: $1.20-2.23 ; \mathrm{p}=.002$ ), RPA (HR: 2.05, 95\%; CI: $1.35-3.09 ; \mathrm{p}=.001$ ), metastatectomy (HR: 0.63, 95\%; CI: $0.46-0.86 ; p=.004$ ) and SRS (HR: $0.53,95 \%$; CI: $0.38-0.72, p<.001$ ) were independent prognostic factors.

Conclusions: In this study, the presence of hypertension was as important in the prognosis of the disease as primary diagnosis, age, metastatectomy and SRS.

Keywords: Brain metastases, prognostic factors, survival, hypertension
Eda Erdiş
(D) Birsen Yücel

ORCID IDs of the authors: E.E. 0000-0003-3003-8643 B.Y. 0000-0002-2083-6866 
ÖZET

Amaç: Beyin metastazının prognozu oldukça kötüdür ve hasta tedavi edilmediği takdirde sağkalım süreci oldukça kısadır. Prognostik faktörlerin belirlenmesinin, beyin metastazlı hastalara yaklaşımda invaziv tedavi girişimleri ya da gereksiz tedavilerden kaçınılması açısından önemi vardır. Bu çalışmada beyin metastazı olan hastalarda prognostik faktörler ile hipertansiyonun sağkalıma etkisi araştırılmıştır.

Yöntem: Bu çalışmada 2007-2018 tarihleri arasında Cumhuriyet Üniversitesi Radyasyon Onkolojisi Merkezine başvuran ve beyin metastazı tanısı alan 463 hastanın verileri retrospektif olarak incelendi.

Bulgular: Median yaş 59 (18-82) idi. 170 (\%37) hastada komorbidite mevcuttu ve bu hastaların \%23'ünün özgeçmişinde hipertansiyon vardı. Birincil tanılarına göre; olguların 271'i (\%58) akciğer kanseri, 91'i (\%20) meme kanseri, 31 'i (\%6) gastrointestinal sistem kanseri, 21’i (\%5) genitoüriner sistem kanseri, 13’ü (\%3) jinekolojik kanser, $11^{\prime}$ i (\%2) primeri bilinmeyen kanser ve 25'i (\%5) diğer kanser gruplarını oluşturmaktaydı. Tanı esnasında hastaların 217 'si (\%47) metastatik evredeydi. Hastaların medyan sağkalımı 4 ay (0-130 ay), ortalama sağkalım ise 9.74+0.6 ay, 1 yıllık sağkalımı \%27, 2 yıllık sağkalımı \%13 olarak belirlenmiştir. Tek değişkenli analizde cinsiyet ( $\mathrm{p}=0.001)$, yaş $(p<0.001)$, hipertansiyon $(p=0.018)$, primer tanı $(p<0.001)$, RPA $(p<0.001)$, lezyon sayis1 $(p<0.001), S R S(p<0.001)$, metastatektomi $(\mathrm{p}<0.001)$ ve primer hastalığın durumu $(\mathrm{p}=0.002)$ istatistiksel olarak anlamlı bulunmuştur. Çok değişkenli analizde; hipertansiyon (HR: $1.29,95 \%$ CI: 1.02-1.71, p=0.027), yaş (HR: $1.39,95 \%$ CI: $1.08-1.77$, $\mathrm{p}=0.008$ ), primer tan1 (HR: 1.63, 95\% CI: 1.20-2.23, $\mathrm{p}=0.002$ ), RPA (HR: 2.05, 95\% CI: 1.35-3.09, $\mathrm{p}=0.001$ ), metastatektomi (HR:0.63, 95\% CI: 0.46-0.86, p=0.004) ve SRS (HR: 0.53, 95\% CI: 0.38-0.72, p<0.001) bağımsiz prognostik faktörler olarak tespit edilmiştir.

Sonuç: Bu çalışmada, hipertansiyonun varlığının hastalığın prognozunda, primer tanı, yaş, metastatektomi ve SRS yapılması kadar önemli olduğunu göstermiştir.

Anahtar sözcükler: Beyin metastazları, prognostik faktörler, sağkalım, hipertansiyon

\section{INTRODUCTION}

Brain metastases are the most common intracranial tumors in adults ${ }^{1}$. Lung, breast, colon carcinoma and melanoma are the most common tumors that metastasize to the brain ${ }^{2}$. Determining prognostic factors is important for the treatment selection of patients with brain metastasis because the prognosis of brain metastases is quite poor ${ }^{2}$.

According to the survival status of the Radiation Therapy Oncology Group (RTOG), prognostic groups called RPA (Recursive Partitioning Analysis) were identified ${ }^{3}$. RPA Group I included patients under 65 years of age with a Karnofsky Performance Status (KPS) of 70 and no extracranial metastasis (except brain), with a median survival period of 7.1 months. Group III KPS had less than 70 patients with a median survival of 2.3 months. In Group II, RPA was evaluated as all patients not included in Group I and Group III, and the median survival period was 4.2 months ${ }^{3}$. However, in recent years, other factors in addition to age, such as performance status, spread of non-brain disease, intracranial tumor-related factors (number, size, type of primary tumor) and number of extracranial metastasis, have also shown prognostic significance ${ }^{4}$.

In cancer patients, the presence of comorbid diseases may be important in regulating the treatment of the disease. Sometimes it can also play a role in the course of the disease.
Hypertension, which is one of the comorbid diseases, is a vascular disease and affects almost all structures in the human body. Some researchers have suggested that there is a relationship between hypertension and cancer development, whilst some have suggested that there may be a relationship with the patient's survival ${ }^{5,6,7}$. Researchers who suggested that it was particularly related to survival thought that high blood pressure affects the microenvironment of cancer cells and adversely affects patients' survival ${ }^{8-10}$. However, the biological mechanisms between hypertension and cancer are not clear. Virdis et al. noted that there may be a correlation between primary cerebral cancer and hypertension in patients with neurofibromatosis with hypertension ${ }^{6}$. Weiss and colleagues tested the relationship between hypertension and brain metastasis by using human autopsy data. These authors reported that metastases could spread to the brain via arterial micro-embolism and suggested that, as arterial blood flow increased, there was an increased rate of metastasis ${ }^{8}$.

In this study, the effect of hypertension on survival in patients with brain metastasis was investigated.

\section{MATERIAL AND METHODS}

This study was performed in accordance with the principles of the declaration of Helsinki and approved by the local ethical committee (Sivas Cumhuriyet University Ethical Committee). 
Data of 463 patients with brain metastasis who were admitted to Radiation Oncology Department of Cumhuriyet University Medical Faculty Training and Research Hospital between 2007 and 2018 were evaluated retrospectively. Demographic, clinical and histopathological data with regard to age, sex, comorbidity, presence of hypertension, primary diagnosis, RPA, number of lesions, metastatectomy status and SRS parameters were obtained by examining patient files and hospital records.

The performance status of the patients was made according to the Karnofsky Performance Scoring. For the evaluation of RPA, patients were grouped according to KPS, age of patients, and non-brain organ metastasis ${ }^{3}$.

All patients underwent 3-D conformal radiotherapy in the Eclipse (ver. 8.6; Varian Medical Systems, Inc. Palo Alto, CA, USA) planning system on a Varian DHX device with a total brain radiotherapy of 10 fractions x 3 Gy total 30 Gy. Stereotactic Radiotherapy was performed with the Tomo $\mathrm{H}$ VoLO planning system (Accuray Inc. Madison, WI, USA). Metastatic lesions of $<2 \mathrm{~cm}$ were prescribed 24 Gy; 18 Gy for 2-3 cm metastatic lesions; and 15 Gy for lesions $>3 \mathrm{~cm}^{11}$.

\section{Statistical analysis}

SPSS version 22.0 was used for the analysis. Descriptive tests were performed to determine the characteristics of the patients (median, mean, standard deviation, etc.). Survival times were calculated with Kaplan-Meier analysis. For the evaluation of prognostic factors, a multivariate analysis and a Cox regression analysis was performed to evaluate independent factors affecting survival. A $p$ value of $\leq 0.05$ was considered statistically significant.

\section{RESULTS}

A total of 463 patients - 303 (66\%) males and 160 (34\%) females - who were admitted to the clinic with brain metastasis were included in the study. The mean age of the patients was 59 (18-82). There were 170 patients $(37 \%)$ who had at least one comorbid disease associated with cancer. These comorbid diseases were as follows: 105 (23\%) hypertension, $63(14 \%)$ diabetes mellitus, $38(8 \%)$ coronary artery disease, and $30(7 \%)$ patients had chronic obstructive pulmonary disease.

According to the primary cancer diagnosis, 271 $(58 \%)$ of the cases had lung, $91(20 \%)$ breast, 31 $(6 \%)$ gastrointestinal, $21(5 \%)$ genitourinary, 13 (3\%) gynecological, 11 (2\%) unknown cancer and $25(5 \%)$ were from other cancer groups.

At the time of diagnosis, 217 patients (47\%) were in metastatic stage. For brain metastasis, 398 $(86 \%)$ patients underwent whole brain radiotherapy and $165(14 \%)$ patients underwent SRS (Stereotactic Radiosurgery).

The median survival of all patients was 4 months (0-130 months); mean survival $9.74+0.6$ months, 1 -year survival $27 \%$ and 2 -year survival was $13 \%$.

Univariate analysis showed that gender, age, hypertension, primary diagnosis, RPA, number of lesions, SRS, metastatectomy, and status of primary disease were statistically significant $(p<$ $.050)$. In this analysis, diabetes mellitus, coronary artery disease and chronic obstructive pulmonary disease did not affect survival $(p>.050)$. Table 1 shows the prognostic factors in univariate analysis. 
Survival Functions

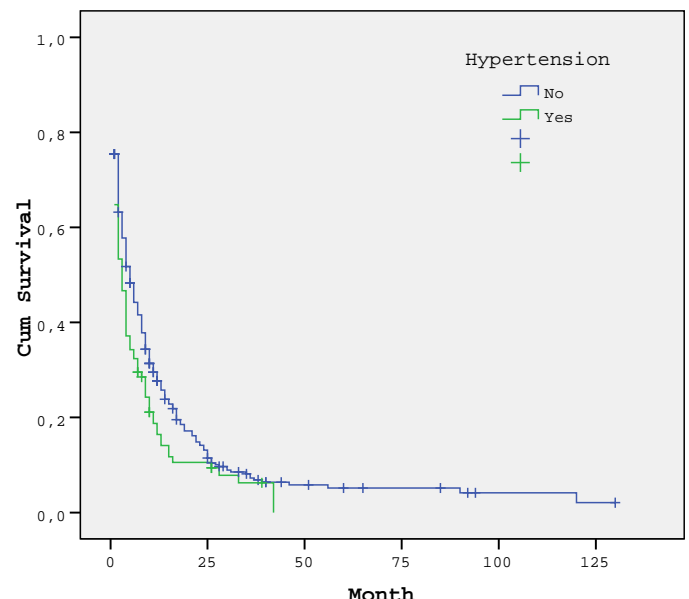

Survival Functions

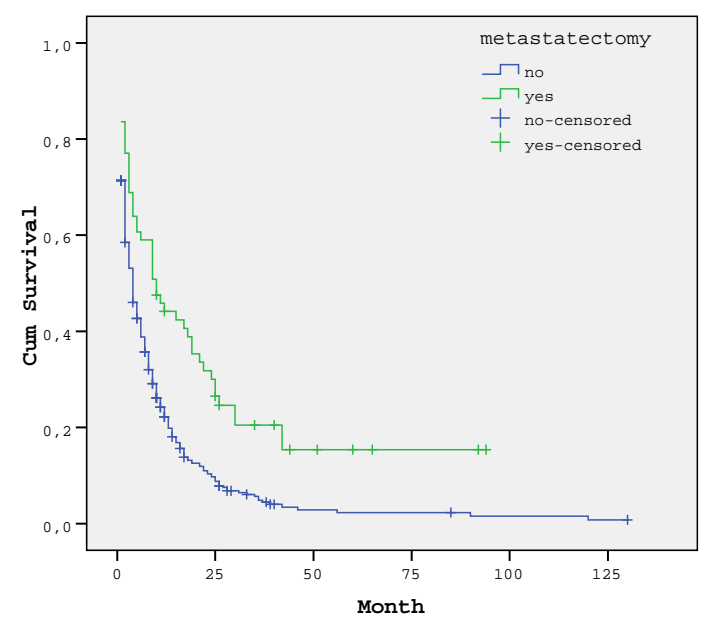

Survival Functions

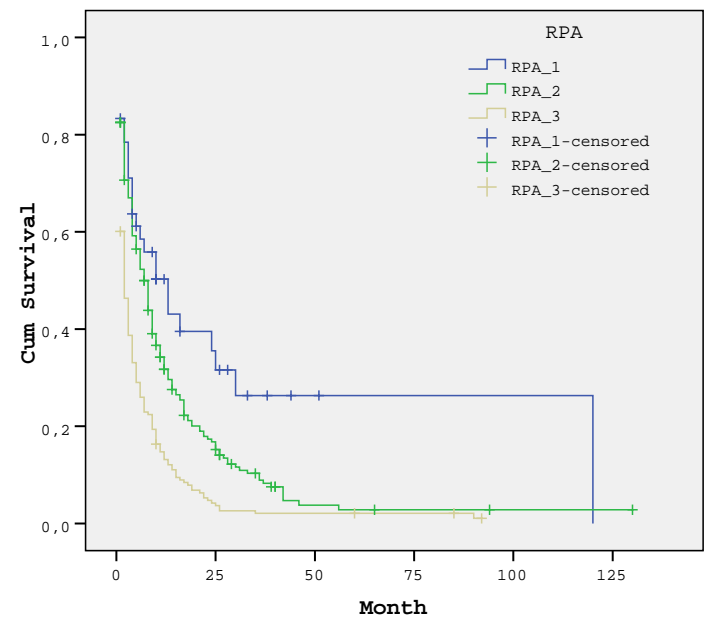

Survival Functions

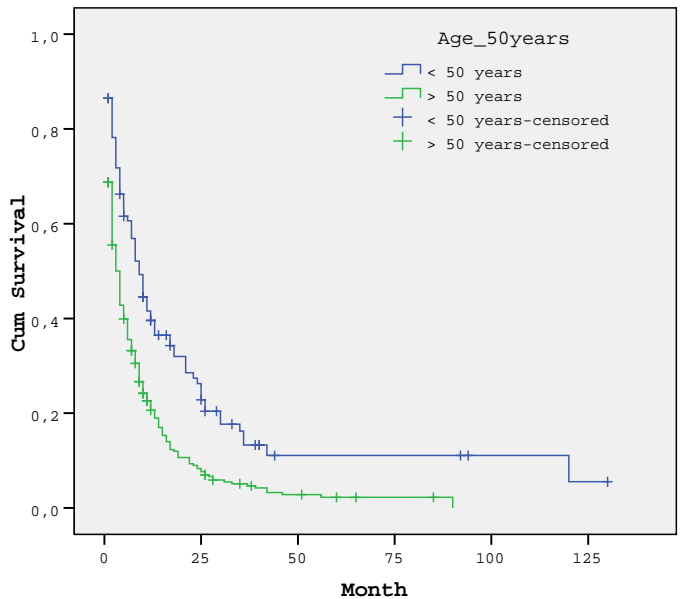

Survival Functions

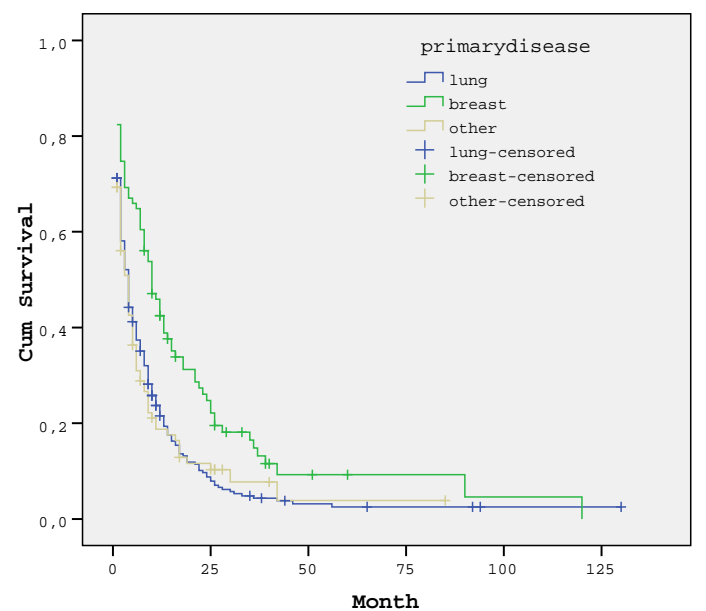

Survival Functions

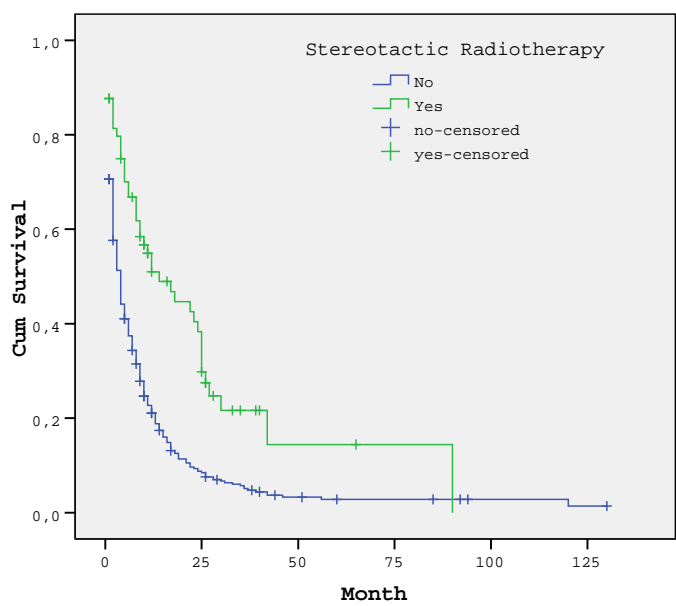

Figure 1: Survival curves of independent prognostic factors 
Table 1: Prognostic factors in univariate analysis.

\begin{tabular}{|c|c|c|c|c|c|}
\hline univariate analysis & No (\%) & $\begin{array}{c}\text { The } 1 \text { year } \\
\text { survival }\end{array}$ & $\begin{array}{c}\text { The } 2 \text { years } \\
\text { survival }\end{array}$ & $\begin{array}{l}\text { Median } \\
\text { survival }\end{array}$ & $p$ value \\
\hline $\begin{array}{l}\text { Gender } \\
\text { Woman } \\
\text { Man }\end{array}$ & $\begin{array}{l}160(34) \\
303(66)\end{array}$ & $\begin{array}{l}35 \\
23 \\
\end{array}$ & $\begin{array}{c}23 \\
8\end{array}$ & $\begin{array}{l}7 \\
4 \\
\end{array}$ & 0.001 \\
\hline $\begin{array}{l}\text { Age } \\
<50 \text { years } \\
\geq 50 \text { years }\end{array}$ & $\begin{array}{l}122(26) \\
341(74)\end{array}$ & $\begin{array}{l}42 \\
22\end{array}$ & $\begin{array}{c}24 \\
9\end{array}$ & $\begin{array}{l}9 \\
3\end{array}$ & $<0.001$ \\
\hline $\begin{array}{l}\text { Comorbidity } \\
\text { No } \\
\text { Yes }\end{array}$ & $\begin{array}{l}293(63) \\
170(37)\end{array}$ & $\begin{array}{l}29 \\
24\end{array}$ & $\begin{array}{l}14 \\
11\end{array}$ & $\begin{array}{l}5 \\
3\end{array}$ & 0.112 \\
\hline $\begin{array}{l}\text { Hypertension } \\
\text { No } \\
\text { Yes }\end{array}$ & $\begin{array}{l}358(77) \\
105(23)\end{array}$ & $\begin{array}{l}30 \\
19\end{array}$ & $\begin{array}{c}14 \\
9\end{array}$ & $\begin{array}{l}5 \\
3 \\
\end{array}$ & 0.018 \\
\hline $\begin{array}{l}\text { Primary } \\
\text { Breast CA } \\
\text { Lung CA } \\
\text { Others } \\
\end{array}$ & $\begin{array}{c}91(19) \\
271(58) \\
101(23)\end{array}$ & $\begin{array}{l}46 \\
24 \\
18\end{array}$ & $\begin{array}{l}25 \\
10 \\
10\end{array}$ & $\begin{array}{l}10 \\
4 \\
4\end{array}$ & $<0.001$ \\
\hline $\begin{array}{l}\text { RPA }^{2} \\
\text { RPA } 1 \\
\text { RPA 2 } \\
\text { RPA 3 } \\
\end{array}$ & $\begin{array}{c}42(9) \\
223(48) \\
198(23)\end{array}$ & $\begin{array}{l}50 \\
34 \\
15\end{array}$ & $\begin{array}{c}40 \\
17 \\
4 \\
\end{array}$ & $\begin{array}{c}13 \\
7 \\
2\end{array}$ & $<0.001$ \\
\hline $\begin{array}{l}\text { Number of lesions } \\
1-3 \\
\text { More than } 3\end{array}$ & $\begin{array}{l}265(57) \\
198(43)\end{array}$ & $\begin{array}{l}33 \\
20\end{array}$ & $\begin{array}{c}18 \\
7\end{array}$ & $\begin{array}{l}5 \\
3\end{array}$ & $<0.001$ \\
\hline $\begin{array}{l}\text { Number of lesions } \\
1 \\
\text { More than } 1\end{array}$ & $\begin{array}{l}156(34) \\
307(66)\end{array}$ & $\begin{array}{l}35 \\
21\end{array}$ & $\begin{array}{c}21 \\
9\end{array}$ & $\begin{array}{l}6 \\
4\end{array}$ & $<0.001$ \\
\hline $\begin{array}{l}\text { SRS }^{\mathbf{3}} \\
\text { No } \\
\text { Yes } \\
\end{array}$ & $\begin{array}{l}398(85) \\
165(15)\end{array}$ & $\begin{array}{l}23 \\
55 \\
\end{array}$ & $\begin{array}{c}9 \\
38 \\
\end{array}$ & $\begin{array}{c}4 \\
14 \\
\end{array}$ & $<0.001$ \\
\hline $\begin{array}{l}\text { Metastasectomy } \\
\text { No } \\
\text { Yes }\end{array}$ & $\begin{array}{c}402(86) \\
61(14)\end{array}$ & $\begin{array}{l}24 \\
44\end{array}$ & $\begin{array}{l}10 \\
30\end{array}$ & $\begin{array}{c}4 \\
10\end{array}$ & $<0.001$ \\
\hline $\begin{array}{l}\text { Status of primary disease } \\
\text { Not conrol } \\
\text { Control }\end{array}$ & $\begin{array}{c}390(84) \\
73(16)\end{array}$ & $\begin{array}{l}25 \\
38 \\
\end{array}$ & $\begin{array}{l}11 \\
24 \\
\end{array}$ & $\begin{array}{l}4 \\
6 \\
\end{array}$ & 0.002 \\
\hline
\end{tabular}

${ }^{1}$ KPS: Karnofsky Performance Status; ${ }^{2}$ RPA: Recursive Partitioning Analysis; ${ }^{3}$ SRS: Stereotactic Radiosurgery

According to multivariate analysis, primary diagnosis, age RPA, metastatectomy, SRS and presence of hypertension were determined as independent prognostic factors. Table 2 presents independent prognostic factors in multivariate analysis. Figure 1 shows the survival curves of independent prognostic factors. 
Table 2: Multivariate Analysis of Factors Affecting Survival

\begin{tabular}{|l|c|c|c|}
\hline Multivariate Analysis & $p$ değeri & Hazard Ratio & \%95 Confidence interval \\
\hline $\begin{array}{l}\text { Hipertansiyon } \\
\text { no vs. yes }\end{array}$ & 0.027 & 1.29 & $1.02-1.71$ \\
\hline $\begin{array}{l}\text { Age } \\
\quad<50 \text { vs. } \geq 50 \text { years }\end{array}$ & 0.008 & 1.39 & $1.08-1.77$ \\
\hline $\begin{array}{l}\text { Primary } \\
\text { breast vs lung } \\
\text { breast vs others }\end{array}$ & $\begin{array}{c} \\
0.001\end{array}$ & 1.63 & $1.26-2.11$ \\
\hline RPA $^{1}$ & 0.248 & 1.63 & $1.20-2.23$ \\
$\begin{array}{l}\text { I vs. II } \\
\text { I vs III }\end{array}$ & 0.001 & 2.05 & $0.84-1.91$ \\
\hline $\begin{array}{l}\text { Metastasectomy } \\
\text { Yok vs. var }\end{array}$ & 0.004 & 0.63 & $1.35-3.09$ \\
\hline $\begin{array}{l}\text { SRS } \\
\text { Yok vs. var }\end{array}$ & $<0.001$ & 0.53 & $0.46-0.86$ \\
\hline
\end{tabular}

${ }^{1}$ RPA: Recursive Partitioning Analysis

\section{DISCUSSION}

In this retrospective study, the effect of the presence of hypertension on survival in patients with brain metastasis was investigated and the presence of hypertension was determined as a poor independent prognostic factor. Not all patients with brain metastasis show the same course. Each tumor cell metastasizing to the brain has different characteristics. Therefore, some studies have reported that the location of the primary tumor affects overall survival ${ }^{12,13}$. Other studies showed that survival rates of breast cancer patients are better than other cancers ${ }^{12-14}$. In their study in patients under 50 years of age with brain metastasis, Nieder et al. reported that the median survival time of primary breast cancer patients was 8.5 months and 6 months in other diseases ${ }^{12}$. In the same study, the survival of primary breast cancer patients was reported to be better in patients over 50 years of age. However, the diagnosis of primary breast cancer for both age groups was not significant in multivariate analysis ${ }^{12}$. Similarly, in this study, primary breast cancer and an age of less than 50 years were found to be independent prognostic factors. The 1- and 2-year overall and median survival rates in patients with primary breast cancer were $46 \%, 25 \%$ and 10 months, respectively. For other diseases, median survival was 4 months. One- and 2-year overall and median survival rates in patients younger than fifty years were $42 \%, 24 \%$, and $9 \%$, respectively. In patients over the age of 50 , it was $22 \%, 9 \%$ and 3 months.

Metastatectomy is another factor that determines the prognosis, and the survival time reported in patients undergoing metastatectomy is quite long 15,16 . In addition, patients with brain metastasis who underwent surgical treatment were found to have statistically significant long-term survival. Early randomized studies have demonstrated that patients with solitary brain metastasis benefit from aggressive local treatment ${ }^{17-19}$. Ferrara et al. found a total survival of 10.2 months after metastatectomy in 100 patients with single brain metastasis ${ }^{20}$. In their study, Duransoy et al. reported a total survival of 9 months and a median survival of 6 months in 62 patients who underwent metastatectomy ${ }^{21}$. In this study, median survival was 10 months in patients who underwent metastatectomy and 4 months in patients who did not. With this result, metastatectomy was determined as an independent prognostic factor in patients with brain metastasis. Bhatnagar et al. recommended SRS alone instead of a whole-brain radiotherapy approach for selected patients with multiple brain metastasis ${ }^{22}$. Ayoma et al. applied SRS to 1-4 metastatic cases 15,23 . Bhatnagar et al. applied SRS to 205 cases with 4-18 metastases and found the median survival as 8 months ${ }^{22}$. In this study, median survival was 14 months in patients undergoing SRS. In addition, SRS was found to be an independent factor affecting prognosis in this study.

Some studies show that metastasis is spread by arterial emboli, and that increased blood pressure causes deterioration of the blood brain barrier and increases the risk of metastasis 6, 24 . However, clinical and experimental data on hypertension and metastases are conflicting. In the cohort study of Edlinger et al., the relationship between hypertension and brain tumors was investigated and increased blood pressure was found to increase the risk of brain tumors, especially for 
meningiomas ${ }^{7}$. Abe et al. investigated the relationship between hypertension and brain metastasis in 232 small-cell lung cancer patients. They reported that hypertension did not increase the risk of brain metastasis ${ }^{25}$. In an experimental study by Fisher et al., the incidence or size of metastasis in hypertensive tumor-bearing rats was not reduced and did not affect the tumor's blood pressure $^{26}$.

More than $60 \%$ of cancer patients are 65 years or older and have a comorbid disease. Age and comorbidity significantly affect cancer diagnosis, treatment and prognosis ${ }^{27}$. The survival rate of patients with comorbidity has been reported by many studies but the underlying mechanism has not been fully explained ${ }^{28-35}$. Hypertension is the most common comorbid disease $(37 \%)$ in malignant patients ${ }^{36}$. Recurrence, metastasis and bilateral tumor development were more common in cancer patients with hypertension ${ }^{37}$. Specifically, in a study of breast cancer patients, Braithwaite et al. reported that hypertension was related to survival in breast cancer even after adjusting for age, race, and other variables ${ }^{9}$. In a study conducted in China in 2013, the presence of hypertension in patients with prostate cancer showed a significant reduction in survival ${ }^{10}$. In our study, the presence of hypertension adversely affected the prognosis of patients. The one-year and two-year overall and median survival period was $30 \%, 14 \%$ and 5 months respectively for patients without hypertension; and 19\%, 9\% and 3 months respectively for patients with hypertension. The results were statistically significant. In addition, the presence of hypertension was recorded as an independent prognostic factor that negatively affected survival in multivariate analysis (HR: $1.29,95 \%$; CI: $1.02-$ $1.71 ; p=.027)$. In this study, the presence of hypertension showed that the prognosis of the disease was as important as primary diagnosis, age, metastatectomy and SRS.

This was a retrospective study. The presence of hypertension was obtained from the background information and patient selection was made accordingly. One of the main limitations of the study was the lack of knowledge regarding the regulation of the blood pressure of the patients and which antihypertensive and chemotherapeutic agents were used.

\section{REFERENCES}

1. Usuki KY, Milano MT, David M, Okunieff P. Metastatic disease: bone, spinal cord, brain, liver, and lung. In: Gunderson LL, Tepper JE, editors.
Clinical radiation oncology. 4nd ed. Elsevier Saunders; 2016. 443-45.

2. Patchell RA. The management of brain metastases. Cancer Treat Rev 2003;29(6):533-40.

3. Gaspar L, Scott C, Rotman M, et al. Recursive partitioning analysis (RPA) of prognostic factors in three Radiation Therapy Oncology Group (RTOG) brain metastases trials. Int J Radiat Oncol Biol Phys 1997;37:745-51.

4. Gerdan L, Segedin B, Nagy V, et al. Brain metastasis from non-small cell lung cancer: prognostic importance of the number of involved extracranial organs. Strahlenther Onkol 2014;190(1):64-7.

5. Colt JS, Schwartz K, Graubard BI, et al. Hypertension and risk of renal cell carcinoma among white and black Americans. Epidemiology 2011;22:797-804.

6. Virdis R, Balestrazzi $\mathrm{P}$, Zampolli $\mathrm{M}$ et al. Hypertension in children with neurofibromatosis. Human Hypertension 1994;8: 395- 397.

7. Edlinger M, Strohmaier S, Jonsson $\mathrm{H}$, et al. Blood pressure and other metabolic syndrome factors and risk of brain tumour in the large population-based Me-Can cohort study. J Hypertens 2012;30(2):290-296.

8.Weiss L, Haydock D, Pickren JW et al. Organ vascularity and metastatic frequency. Am J Path 1980; 101:101-113.

9. Braithwaite D, Tammemagi CM, Moore DH, Ozanne EM, Hiatt RA, Belkora J, West DW, Satariano WA, Liebman M, Esserman L. Hypertension is an independent predictor of survival disparity between African-American and white breast cancer patients. Int $\mathrm{J}$ Cancer 2009;124:1213-1219.

10. Hua Xu, Li-min Zhang, Jun Liu et al. The association between overall survival of prostate cancer patients and hypertension, hyperglycemia, and overweight in Southern China: a prospective cohort study. J Cancer Res Clin Oncol 2013;139:943-951.

11. Shaw E, Scott C, Souhami L, et al. Single dose radiosurgical treatment of recurrent previously irradiated primary brain tumors and brain metastases: final report of RTOG protocol 9005. Int J Radiat Oncol Biol Phys 2000; 47:291.

12. Nieder C, Grosu AL, Spanne O, Andratschke $\mathrm{NH}$, Geinitz $\mathrm{H}$. Brain metastases in patients under 50 years of age: Retrospective analysis. ClinExp Metastasis 2012;29(8):949-56. 
13. Soffietti R, Cornu P, Delattre JY, Grant R, Graus F, Grisold W, et al. Brain metastases. In: Gilhus NE, Barnes MP, Brainin M (Ed). European Handbook of Neurological Management. 2nd ed. Oxford: Blackwell Publishing Ltd. 2011; 437-45.

14. Hall WA, Djalilian HR, Nussbaum ES, Cho $\mathrm{KH}$. Long-term survival with metastatic cancer to the brain. Med Oncol 2000;17(4):279-86.

15. Aoyama $H$, Shirato $H$, Tago $M$, et al. Stereotactic radiosurgery plus whole-brain radiation therapy vs stereotactic radiosurgery alone for treatment of brain metastases: a randomized controlled trial. JAMA 2006; 295:2483-91.

16. Billings PS, Miller DL, Allen MS, et al. Surgical treatment of primary lung cancer with synchronous brain metastases. J Thorac Cardiovasc Surg 2001; 122: 548-53.

17. Patchell RA, Tibbs PA, Walsh JW, Dempsey RJ, Maruyama Y, Kryscio RJ et al. A randomized trial of surgery in the treatment of single metastases to the brain. N Engl J Med 1990; 322(8): 494-500.

18. Patchell RA, Tibbs PA, Walsh JW, Dempsey RJ, Maruyama Y, Kryscio RJ et al. Postoperative Radiotherapy in the treatment of single metastases to the brain: a randomized trial. JAMA 1998; 280(17): 1485-9.

19. Vecht CJ, Haaxma-Reiche H, Noordijk EM, Padberg GW, Voormolen JH, Hoekstra FH, et al. Treatment of single brain metastasis: radiotherapy alone or combined with neurosurgery? Ann Neurol 1993; 33(6):583-90.

20. Ferrara M, Bizzozzero L, Talamonti $G$ et al. Surgical treatment of 100 single brain metastases. Analysis of the results. J Neurosurg Sci 1990; 34(3-4): 303-308.

21. Duransoy YK, Selcuki M, Gokce T, Duransoy A. Prognostic Factors in Metastatic Brain Tumors: Study of 62 Patients. J Neurol Sci 2012; 29(4): 732-743.

22. Bhatnagar AK, Flickinger JC, Kondziolka D, et al. Stereotactic radiosurgery for four or more intracranial metastases. Int $\mathrm{J}$ Radiat Oncol Biol Phys 2006; 64:898-903.

23. Andrews DW, Scott CB, Sperduto PW, et al. Whole brain radiation therapy with or without stereotactic radiosurgery boost for patients with one to three brain metastases: phase III results of the RTOG 9508 randomised trial. Lancet 2004; 363:1665-72.
24. Delattre JY, Krol G, Thaler HT et al. Distribution of brain metastaes. Arch Neurol 1988;45:741-744.

25. Abe E. Sahmoun, L. Douglas Case, et al. Hypertension And Risk Of Brain Metastasis From Small Cell Lung Cancer: A Retrospective FollowUp Study. Anticancer Research 2004; 24: 3115120.

26. Fisher ER, Hellstrom HR, Fisher b. Experimental study of relationship between hypertension and tumor growth and metastases. Br J Cancer 1968;22(2):342-45.

27. Yancik R, Ries LA. Cancer in older persons: an international issue in an aging world. Semin Oncol. 2004;31(2):128-136.

28. Cronin-Fenton DP, Nørgaard M, Jacobsen J, et al. Comorbidity and survival of Danish breast cancer patients from 1995 to 2005 . Br J Cancer. 2007;96(9):1462-1468.

29. Iversen LH, Nørgaard M, Jacobsen J, Laurberg S, Sørensen HT. The impact of comorbidity on survival of Danish colorectal cancer patients from 1995 to 2006 - a populationbased cohort study. Dis Colon Rectum. 2009;52(1):71-78.

30. Land LH, Dalton SO, Jensen MB, Ewertz M. Impact of comorbidity on mortality: a cohort study of 62,591 Danish women diagnosed with early breast cancer, 1990-2008. Breast Cancer Res Treat 2012;131(3): 1013-1020.

31. Asmis TR, Ding K, Seymour L, et al; National Cancer Institute of Canada Clinical Trials Group. Age and comorbidity as independent prognostic factors in the treatment of non small-cell lung cancer: a review of National Cancer Institute of Canada Clinical Trials Group trials. J Clin Oncol 2008;26(1):54-59.

32. Roxburgh C, McDonald A, Salmond J, et al. Adjuvant chemotherapy for resected colon cancer: comparison of the prognostic value of tumour and patient related factors. Int $\mathrm{J}$ Colorectal Dis 2011;26(4):483-492.

33. Sarfati D, Hill S, Blakely T, et al. The effect of comorbidity on the use of adjuvant chemotherapy and survival from colon cancer: a retrospective cohort study. BMC Cancer 2009;9:116.

34. Grønberg BH, Sundstrøm S, Kaasa S, et al. Influence of comorbidity on survival, toxicity and health-related quality of life in patients with advanced non-small-cell lung cancer receiving platinum-doublet chemotherapy. Eur J Cancer 2010;46(12):2225-2234. 
35. Lüchtenborg M, Jakobsen E, Krasnik M, Linklater KM, Mellemgaard A, Møller H. The effect of comorbidity on stage-specific survival in resected non-small cell lung cancer patients. Eur J Cancer 2012;48(18): 3386-3395.

36. Piccirillo JF, Tierney RM, Costas I, Grove L, Spitznagel EL Jr. Prognostic importance of comorbidity in a hospital-based cancer registry. JAMA 2004;291(20):2441-7.
37. Shin DW, Baik YJ, Kim YW, Oh JH, Chung $\mathrm{KW}$, Kim SW, Lee WC, Yun YH, Cho J. Knowledge, attitudes, and practice on second primary cancer screening among cancer survivors: a qualitative study. Patient Educ Couns 2011; 85: 74-78. 